\title{
PENGEMBANGAN MODUL MATEMATIKA BERBASIS OPEN ENDED PROBLEM PADA MATERI HIMPUNAN
}

\author{
Apliana Gadi Mayi ${ }^{1}$, Kenys Fadhilah Zamzam² \\ 1,2 IKIP Budi Utomo Malang \\ mayiapli@yahoo.com
}

\begin{abstract}
Abstrak
Tujuan penelitian ini adalah menghasilkan modul Matematika berbasis Open ended problem pada materi Himpunan yang Valid, Praktis, dan Efektif yang di gunakan di kelas VII SMP Islam Baiturrohmah Malang. Model pengembangan yang digunakan adalah model pengembangan ADDIE, yang meliputi Analysis, dimana peneliti melakukan analisis kurikulum, kebutuhan, dan karakteristik siswa. Pada tahap Design, peneliti melakukan perancangan garis besar modul. Pada tahap Development, peneliti mengembangkan modul sesuai revisi awal. Pada tahap implementation, modul di ujicobakan kelas VII SMP Islam Baiturrohmah Malang dengan menyebar angket respon siswa. Pada tahap Evaluation, dilakukan analisis hasil angket respon siswa. Penelitian ini menghasilkan modul matematika Materi Himpunan berbasis Open ended problem. Hasil penelitian menunjukkan bahwa: (1) validator ahli materi mendapatkan skor dengan rata-rata 3,08 dan 3,47 dengan kategori Sangat Valid; (2) penilaian dari validator ahli praktisi mendapatkan rata-rata 3,49 dimana masuk kategori sangat valid. Respon siswa mendapatkan skor rata-rata 3,27 dengan kategori Sangat Setuju, dan hasil belajar tingkat penguasaan siswa mencapai 85,71\% dengan kategori sangat baik. Berdasarkan analisis data di atas dapat di tarik kesimpulkan bahwa modul matematika materi himpunan berbasis Open ended problem valid, praktis, dan efektif untuk digunakan sabagai bahan ajar untuk siswa SMP/MTs Kelas VII.
\end{abstract}

Kata Kunci: modul, pembelajaran himpunan, open ended problem

\begin{abstract}
The purpose of this study was to produce an Open ended problem based Mathematics module on the Valid, Practical, and Effective set material that was used in class VII of Baiturrohmah Islamic Middle School in Malang. This research is a development research with the development of ADDIE, which includes Analysis, where the researcher analyzes the curriculum, needs, and characteristics of students. At the Design stage, the researcher designs the module outline. At the Development stage, researchers develop modules according to the initial revision. At the implementation stage, the module was tested in class VII of Baiturrohmah Islamic Islamic Junior High School Malang by distributing student response questionnaires. In the Evaluation stage, an analysis of the results of student response questionnaires was carried out. This study produced a mathematical module on the set of materials based on Open ended problems. The results showed that: (1)
\end{abstract}


the material expert validator got a score with a mean of 3.08 and 3.47 in the Very Valid category; (2) the assessment of the expert practitioner validator gets an average score of 3.49 with a very valid category. As for the response of students to get an average score of 3.27 with the Strongly Agree category, and the learning outcomes of students' mastery level reached $85,71 \%$ with very good categories. Based on the data analysis described above, it can be concluded that the mathematics module on Open ended problem-based set of material is valid, practical, and effective to be used as teaching materials for Grade VII junior high school / MTs students.

Keywords: module, set learning, open ended problem

\section{PENDAHULUAN}

Matematika merupakan salah satu mata pelajaran di sekolah yang mempunyai peranan penting meningkatkan kualitas siswa, dimana matematika adalah sarana dalam berpikir untuk berpikir secara logis dan sistematis. Risnawati (2008) menyatakan bahwa tujuan membelajarkan matematika adalah untuk membekali siswa sehingga memiliki kemampuan berpikir secara logis, analitis, sistematis, kritis dan kreatif serta kemampuan dalam kerjasama. Hal ini diharapkan kemampuan siswa dapat berkembang dalam memecahkan masalah yang berkaitan dengan kehidupan sehari-hari.

Peran guru sangat dibutuhkan dalam proses pembelajaran matematika di sekolah untuk mencapai tujuan matematika tersebut. Pada dasarnya kebanykan guru masih bertumpu pada buku teks dimana menurut Depdiknas (2008) menyatakan buku teks mempunyai beberapa kelemahan salah satunya tidak terdapat cara menggunakannya, materi pendukung yang masih kurang, cara menyelesaikan soal masih kurang sehingga mengakibatkan pola pikir siswa kurang berkembang dan siswa kesulitan dalam pembentukan konsep berpikir dimana berpengaruh dalam pemahamannya terhadap materi yang didapat. Modul menjadikan alternatif terbaik untuk mengatasi berbagai masalah yang disebabkan dari buku teks.

Pengembangan modul dibutuhkan para guru untuk mewujudkan pembelajaran yang lebih efisien, efektif, dan sesuai dengan tujuan atau kompetensi yang diharapkan. Selain itu pengembangan modul diperlukan untuk memenuhi standar kurikulum yang ada sehingga memudahkan siswa dalam pemecahan masalah. Pembelajaran akah lebih efektif dan efisien serta relevan melalui sistem pembelajaran dengan modul 
(Wena 2009: 230). Pembelajaran modul mempunyai beberapa keunggulan jika dibandingkan dengan pembelajaran secara konvensional.

Open ended problem atau pembelajaran sesuai dengan masalah menurut Shimada dan Becker (1997) menyatakan pendekatan pembelajaran dimana siswa dihadapkan atau disajikan dalam bentuk permasalahan yang mempunyai bentuk penyelesaian lebih dari satu dinamakan pendekatan Open ended problem. Open ended problem membuat siswa berpikir mencari cara atau strategi sesuai dengan kemampuan dalam mengelaborasi dari permasalahan yang didapat.

Noer (2011) juga memberikan pendapatnya bahwa melalui pendekatan Open ended problem dapat memberikan pengaruh secara signifikan dalam peningkatan taraf kreativitas siswa dalam penyelesaian masalah. Untuk itu pengembangan modul dengan pendekatan Open ended problem diharapkan menjadi media pembelajaran yang efektif dan efisien dalam menumbuhkembangkan

kreativitas siswa dalam penyelesaian masalah.

Berdasarkan uraian yang telah dijelaskan, peneliti merasa perlu untuk melakukan penelitian tentang pengembangan modul. Penelitian ini mempunyai judul yaitu Pengembangan Modul
Matematika Berbasis Open ended problem Pada Materi Himpunan Siswa Kelas VII SMP Islam Baiturrohmah Malang. Tujuan penelitian ini menghasilkan modul matematika berbasis Open ended problem pada materi himpunan yang valid, praktis, dan efektif yang digunakan di kelas VII SMP Islam Baiturrohmah Malang.

\section{METODE PENELITIAN Model Pengembangan}

Penelitian ini merupakan penelitian pengembangan atau Research and Development (R \& D). Model pengembangan yang dipakai adalah model pengembangan ADDIE (Benny A. Pribadi) yaitu meliputi tahap Analysis (Analisis), tahap Design (Perancangan), tahap Development (Pengembangan), tahap Implementation (Implementasi), dan tahap Evaluation (Evaluasi).

\section{Desain Uji Coba}

Uji coba produk modul berbasis Open ended problem ini didesain dengan menggunakan keterbacaan dan validasi produk. Uji keterbacaan dilakukan dengan skala kecil yakni oleh 3 orang siswa-siswi dengan cara pengisian lembar angket, dan tanggapan guru Matematika dengan mengisi lembar angket tanggapan guru. Sedangkan untuk validasi menggunakan lembar validasi yang berisi beberapa kriteria penilaian modul akan di isi oleh 
validator ahli media dan validator ahli materi.

Setelah modul divalidasi oleh validator ahli media dan ahli materi kemudian direvisi berdasarkan atas masukan dan saran yang didapat. Produk berupa modul akan diuji coba kepada siswa untuk mengetahui apakah modul layak dan dapt digunakan dalam proses kegiatan belajar mengajar. Uji coba dilakukan terhadap 14 siswa untuk menilai modul. Siswa diminta mempelajari modul yang dikembangkan dan mengisi angket respon siswa kemudian dianalisis. Jika respon baik dan hasil angket respon valid maka modul layak untuk digunakan dalam proses belajar mengajar.

\section{Subjek Penelitian}

Penelitian pengembangan ini memakai subjek coba antara lain: validator ahli materi, validator ahli media, guru Matematika SMP Islam Baiturrohmah Malang. Sedangkan uji coba terhadap kepraktisan penggunaan modul matematika dilakukan terhadap 14 orang siswa SMP Islam

Baiturrohmah Malang.

\section{Teknik Pengumpulan Data}

Teknik pengumpulan data yang digunakan dalam penelitian ini antara lain observasi, validasi ahli materi, ahli media dan guru matematika SMP Islam Baiturrohmah Malang serta angket respon siswa. Observasi awal adalah dilakukan pengamatan langsung terhadap sekolah dan siswa, serta untuk mengamati dan mencatat kegiatan pembelajaran di kelas dengan menggunakan modul matematika berbasis open ended problem.

Lembar penilaian ahli dan praktisi yang berupa lembar validasi yang bertujuan untuk menilai bagaimana hasil kelayakan dan kevalidan modul yang telah dikembangkan. Penilaian modul ini dilakukan oleh validator. Untuk mengetahui bagaimana respon dan tanggapan para siswa terhadap modul diberikan angket respon siswa. Jika siswa memberikan respon baik dan hasilnya menunjukkan kriteria valid maka modul efektif untuk digunakan dalam proses belajar mengajar. Angket respon siswa di isi oleh siswa kelas VII SMP Islam Baiturrohmah.

\section{Instrumen Pengumpulan Data}

Instrumen dalam penelitian merupakan alat yang dapat digunakan dalam pengambilan data. Perlu pemilihan instrument yang tepat di dalam penelitian, hal ini diharapkan dapat menghasilkan data yang akurat. Instrumen dalam penelitian ini yang akan digunakan dalam pengembangan modul matematika berbasis open ended problem ini adalah lembar validasi ahli dan praktisi dan lembar angket respon siswa.

\section{Teknik Analisis Data}


Data yang didapat dari lembar validasi modul dianalisis secara kuantitatif dan kualitatif. Tujuan dari analisis data ini untuk menghasilkan modul yang valid, efektif, dan efisien. Analisis ini dilakukan setelah modul di uji cobakan. Data yang terkumpul kemudian di analisis sesuai dengan validasi dan angket respon siswa.

Data kualitatif pada penelitian pengembangan modul ini didapat dari saran dan masukan dari validator ahli dan validator praktisi terhadap modul matematika yang dikembangkan. Saran dan masukan tersebut kemudian di analisis dan dibuat pertimbangan untuk diperbaiki atau direvisi pada modul, sehingga modul yang dihasilkan efektif untuk digunakan dalam proses kegiatan belajar mengajar.

Data kuantitatif didapat dari rata-rata skor penilaian validator dan hasil angket respon dari siswa. Penilaian lembar validasi dalam penelitian ini di dapat dari validator ahli media dan praktisi yang berupa skor rata-rata $(\bar{x})$. Untuk mengetahui peringkat nilai akhir setiap butir dengan cara jumlah nilai yang diperoleh dibagi dengan banyaknya responden yang menjawab angket tersebut. Dapat dirumuskan perhitungannya adalah $\bar{x}=\frac{\sum x i}{n}$ dengan $\bar{x}=$ nilai rata-rata, $\quad \sum x i=$ jumlah nilai jawaban validator, dan $n=$ banyaknya data.

Tabel 1 Kriteria Validasi

\begin{tabular}{|l|c|c|}
\hline \multicolumn{1}{|c|}{ Rentang nilai } & Kriteria validasi & Keterangan \\
\hline $3,25 \leq \bar{x} \leq 4,00$ & Sangat valid & Tidak revisi \\
\hline $2,55 \leq \bar{x}<3,25$ & Valid & Tidak revisi \\
\hline $1,75 \leq \bar{x}<2,55$ & Kurang valid & Revisi \\
\hline $\bar{x}<1,75$ & Tidak valid & Revisi \\
\hline
\end{tabular}

$\begin{array}{ccc}\text { Hasil } & \text { yang } & \text { diperoleh } \\ \text { berdasarkan } & \text { rumus } & \text { tersebut, }\end{array}$ kemudian untuk mengetahui tingkat kevalidan modul digunakan interval sebagai dasar pengambilan keputusan untuk merevisi modul atau tidak, dijabarkan dalam Tabel 1.

Kelayakan yang ditetapkan dalam penelitian ini berada dalam ketegori "valid". Jadi validator yang yang memberikan hasil akhir pada kategori "valid", maka produk pengembangan yaitu modul layak digunakan sebagai bahan ajar. Namun, apabila analisis data hasil penelitian pengembangan ini masuk dalam kategori "Tidak Valid" pada penelitian ini akan akan dijadikan bahan pertimbangan untuk merevisi bahan ajar sebelum diujicobakan. Sedangkan kriteria kepraktisan penggunaan modul dalam proses pembelajaran tercapai jika tingkat 
kepraktisan minimal yang didapat adalah praktis.

\section{HASIL DAN PEMBAHASAN}

Tahap Analysis (Analisis), yang dilakukan adalah analisis kurikulum pada materi himpunan serta analisis pada karakteristik siswa. Hasil analisis kompotensi serta analisis karakteristik siswa diperoleh dari modul yang akan dikembangkan sesuai menggunakan berbasis Open ended problem.

Pada tahap Design (Perancangan), dilakukan beberapa kegiatan yaitu menyusun garis besar modul, menyiapkan buku referensi, gambar, materi, soal-soal, serta menyusun instrumen penilaian dalam modul dimana akan digunakan sebagai alat ukur untuk mengukur kualitas modul yang akan dikembangkan. Instrumen penelitian ini meliputi lembar angket penilaian modul bagi ahli materi dan ahli media, tes hasil belajar, dan angket respon siswa. Setelah instrumen penelitian selesai disusun kemudian divalidasi oleh dosen. Instrumen penelitian tersebut direvisi sesuai dengan saran dari validator hingga valid dan siap digunakan.

Tahap

Development

(Pengembangan). Pada tahapan ini, peneliti akan mengembangkan modul matematika materi Himpunan yang bertumpu pada saran validator dengan desain awal yang telah dirancang. Saransaran dari para dosen pembimbing dapat digunakan dalam pengembangan modul. Setelah selesai, modul matematika materi himpunan dinilai oleh satu ahli media dan satu ahli materi menggunakan angket penilaian modul. Revisi modul dilakukan setelah mendapatkan perbaikan dan saran dari para ahli. Berdasarkan penilaian, diperoleh skor rata-rata penilaian modul yaitu 3,27 dimana dalam kegori sangat valid, oleh karena itu dapat dikatakan menurut para validator, bahwa modul yang dikembangkan telah valid.

Pada tahap Implementation (Implementasi), modul yang dikembangkan diujicobakan dalam pembelajaran matematika di sekolah. Implementasi dilaksanakan di kelas VII SMP Islam Baiturrohmah mulai tanggal 19 Juli sampai dengan 30 Juli 2018. Siswa tampak antusias melaksanakan pembelajaran menggunakan modul. Ketuntasan Post Test telah mencapai KKM yang di tentukan dengan rata-rata skor 78,78 berada dalam kategori baik.

Selain tes hasil belajar, maupun respon siswa terhadap modul juga baik dengan skor rata-rata 3,27 dimana memenuhi pada kategori sangat baik. Pengisisan hasil angket siswa menunjukkan modul matematika yang dikembangkan pada materi Himpunan layak/ 
efektif dan praktis digunakan dalam proses kegiatan pengajaran di sekolah.

Tahap Evaluation (Evaluasi), pada tahapanan ini yang akan dilakukan adalah revisi modul. Hasil pengamatan para siswa selama proses implementasi dijadikan acuan dalam merevisi modul. Selain itu juga beberapa saran yang di dapat dari guru. Setelah revisi maka akan dihasilkan produk akhir dengan judul Modul Matematika Berbasis Open ended problem materi Himpunan untuk Siswa Kelas VII SMP Islam Baiturrohmah Malang. Berdasarkan uraian yang dibahas di atas maka dapat dikatakan modul yang dikembangkan masuk pada kualitas baik yaitu memenuhi standar kevalidan, kepraktisan, dan keefektifan.

Kualitas modul pada materi Himpunan berbasis Open ended problem untuk siswa kelas VII SMP yang telah di kembangkan antara lain:

a. Ditinjau pada aspek kevalidan, adalah hasil penilaian yang dilakukan oleh ahli materi dan ahli praktisi, memperoleh hasil rata-rata skor 3.34 dimana pada kategori valid.

b. Ditinjau dari aspek praktis, yaitu modul sudah tersusun secara sistematis, terperinci, dan sesuai dengan tujuan pembelajaran dan dalam penggunaan modul sudah memuat petunjuk penggunaan, cara menyelesaikan soal serta mempunyai kunci jawaban berbasis Open ended problem.

c. Ditinjau dari aspek keefektifan, yaitu dalam uji coba produk dan mengerjakan tes, siswa sangat antusias dalam mengerjakan tugas dalam modul sehingga dikatakan efektif dalam proses pembelajaran. Dapat disimpulkan modul yang dirancang telah efektif digunakan dalam proses belajar mengajar matematika di sekolah

d. Hasil belajar dilihat berdasarkan pada hasil tingkat penguasaan siswa sudah mencapai $85,71 \%$ dimana 12 siswa dari 14 jumlah siswa keseluruhan sudah mencapai KKM dan tes hasil belajar (Post Test) diperoleh rata-rata kelas yaitu 78,78 dan dari angket respon pada siswa rata-ratanya memperoleh 3,27 dimana mencapai kategori sangat baik.

\section{KESIMPULAN DAN SARAN}

Adapun kesimpulan yang diperoleh berdasarkan uraian di atas antara lain sebagai berikut. Pengembangan modul pada materi Himpunan berbasis Open ended problem untuk siswa SMP Kelas VII menerapakan model pengembangan ADDIE yang terdiri dari lima tahap, yaitu: tahap Analysis (Analisis), tahap Design (Perancangan), tahap Development 
(Pengembangan), tahap Implementation (Implementasi), dan tahap Evaluation (Evaluasi).

Kualitas modul pada materi Himpunan berbasis Open ended problem untuk siswa kelas VII SMP yang telah di kembangkan antara lain: (1) Pada aspek kevalidan adalah dinilai dari ahli materi dan ahli praktisi, modul yang dirancang diperoleh rata-rata 3,34 dimana pada kategori valid. Sehingga modul yang dirancang dinyatakan valid. (2) Ditinjau dari aspek praktis, modul sudah tersusun secara sistematis, terperinci, dan sesuai dengan tujuan pembelajaran dan dalam penggunaan modul sudah memuat petunjuk penggunaan, cara menyelesaikan soal serta mempunyai kunci jawaban berbasis Open ended problem. (3) Ditinjau dari aspek keeektifan, dalam uji coba produk dan mengerjakan tes, siswa sangat antusias dalam mengerjakan tugas sehingga serta berani dalam menyampaikan pendapatnya secara tertulis maupun lisan sehingga modul dapat dapat dikatakan efektif dalam proses pembelajaran.

Hasil belajar dilihat dari hasil tingkat penguasaan siswa sudah mencapai 85,71\% dimana 12 siswa dari 14 jumlah siswa keseluruhan sudah mencapai KKM dan tes hasil belajar (Post Test) diperoleh ratarata kelas yaitu 78,78 dan dari hasil angket respon siswa diperoleh rata-rata skornya 3,27 berada pada kategori baik.

Adapun saran yang dapat dilakukan untuk penelitian selanjutnya antara lain modul matematika materi Himpunan berbasis disempurnakan lagi baik materi maupun tampilannya dan disesuaikan dengan kebutuhan. Selain itu perlu dikembangkan bahan ajar lain berupa handout atau lainnya yang berbasis open ended problem.

\section{DAFTAR PUSTAKA}

Becker, J. P., \& Shimada, S. 1997. The Open-Ended Approach: A New Proposal for Teaching Mathematics. Reston, Virginia: National Council of Teachers of Mathematics.

Depdiknas. 2006. Peraturan Menteri Pendidikan Nasional No 22 Tahun 2006 Tentang Standar Isi untuk Satuan Pendidikan Dasar dan Menengah.

Depdiknas. 2008. Panduan Pengembangan Bahan Ajar. Jakarta: Depdiknas.

Noer, S. H. 2011. Kemampuan Berpikir Kreatif Matematis Dan Pembelajaran Matematika Berbasis Masalah Open Ended. Jurnal Pendidikan Matematika.

Pribadi, B. 2009. Model Desain Sistem Pembelajaran. Jakarta: Dian. 
Mayi, A. G., Zamzam, K. F.

Pengembangan Modul Matematika Berbasis Open Ended Problem pada Materi Himpunan

Risnawati. 2008. Strategi

Pembelajaran Matematika.

Suska Press. Pekanbaru

Wena, Made. 2009. Strategi

Pembelajaran Inovatif

Kontemporer. Jakarta: Bumi

Aksara 2014. 